\title{
Geopolitik Bantuan Luar Negeri Dari Perang Dingin sampai Globalisasi
}

\author{
Dion Maulana Prasetya* \\ dionprasetya@gmail.com
}

\begin{abstract}
Abstrak
Geopolitik bantuan luar negeri menyiratkan adanya hubungan tak terpisahkan antara geopolitik dan bantuan luar negeri. Dengan kata lain, preferensi pemberian bantuan luar negeri sangat dipengaruhi oleh faktor-faktor geopolitik. Artikel ini berusaha memaparkan kaitan antara geopolitik dan bantuan luar negeri. Lebih khusus tulisan ini membahas preferensi bantuan luar negeri Amerika Serikat (AS) yang sangat dipengaruhi oleh faktor geopolitik. Tulisan ini terbagi menjadi tiga bagian. Bagian pertama membahas hubungan antara Marshall Plan dengan geopolitik. Bagian kedua dari tulisan ini membahas tentang konflik internal Yunani yang menjadi faktor penentu lahirnya Marshall Plan. Sedangkan bagian ketiga membahas mengenai upaya AS dalam memerangi terorisme melalui bantuan luar negeri. Dari hasil studi terlihat bahwa terjadi perubahan preferensi pemberian bantuan luar negeri berdasarkan faktor-faktor geopolitik.
\end{abstract}

Kata kunci: bantuan luar negeri, geopolitik, Marshall Plan, terorisme

\begin{abstract}
Geopolitics of foreign aids shows a relation of geopolitic can not be separated with foreign aids. In other words, foreign aids preference will be influenced by geopolitics factors. This article tries to explain the correlation between geopolitics and foreign aids. To be more specific, this article talks about the United States foreign aids preference that is influenced by geopolitics factors. This article is divided into three parts. The first part discusses the correlation between Marshall Plan and geopolitics. The second part examines the Greek civil war that became the decisive factor of the Marshall Plan. Whereas the third part discusses about the US efforts on war against terrorism through foreign aids. The study shows that there is a change on the foreign aids preference that is influenced by geopolitics factors.
\end{abstract}

Keywords: foreign aids, geopolitics, Marshall Plan, terrorism

\section{Pendahuluan}

Selama ini studi mengenai bantuan luar negeri hanya berkisar pada perdebatan mengenai efektivitas (Easterly, 2003; Collier dan Dollar, 2004; Calderisi, 2006) maupun telaah kritis terhadapnya (Parvitt, 1986; Heertz, 2004; Woods, 2006; Grant dan Nijman, 1998). Sehingga perdebatannya terus berputar pada jenis-jenis pertanyaan seperti "apakah bantuan luar negeri efektif dalam mengangkat perekonomian suatu negara?" atau "apakah bantuan luar negeri dapat dimanfaatkan dengan tepat oleh negara penerimanya?”. Hal ini

*Korespondensi: Mahasiswa Jurusan Ilmu Hubungan Internasional, Program Pascasarjana Universitas Airlangga. Dion Maulana Prasetya, Jl. JA Suprapto 1C no. 268 Malang, Jawa Timur. 
memunculkan perdebatan yang tidak berujung di kalangan pakar hubungan internasional karena berkaitan erat dengan aspek-aspek normatif.

Berangkat dari gambaran mengenai studi bantuan luar negeri tersebut, tulisan ini hendak membahas satu hal yang luput dari ruang diskusi selama ini, yakni mengenai geopolitik bantuan luar negeri. Geopolitik bantuan luar negeri menyiratkan adanya hubungan tak terpisahkan antara geopolitik dan bantuan luar negeri. Dengan kata lain, preferensi pemberian bantuan luar negeri sangat dipengaruhi oleh faktor-faktor geopolitik. Tulisan ini akan menggunakan studi kasus pemberian bantuan luar negeri AS kepada Eropa dalam bentuk European Reconstruction Program (Marshall Plan) sebagai titik awal bagaimana geopolitik sangat memengaruhi preferensi pemberian bantuan luar negeri. Setelah itu akan dibahas mengenai penyaluran bantuan luar negeri sebagai upaya memerangi terorisme yang juga sangat terkait dengan faktor geopolitik.

\section{Marshall Plan dan Geopolitik}

Bantuan luar negeri AS terhadap Yunani dan Turki pada tahun 1947 merupakan langkah awal dari berjalannya Marshall Plan/European Recovery Program. Yunani merupakan negara yang paling awal mendapatkan bantuan finansial dan militer AS. Nilai bantuan sebesar 400 juta dollar AS diajukan oleh Presiden Truman untuk membantu Yunani mengatasi konflik internal yang terjadi di negara tersebut sejak tahun 1946 dan sebagai respon atas semakin berkembangnya ideologi komunisme di Eropa Timur. Gagasan Truman tersebut disampaikan satu bulan setelah Czechoslovakia dikuasai oleh rezim komunis - yang menjadi penanda penting akan semakin kuatnya infiltrasi komunisme di bawah pengaruh Uni Soviet. Bantuan luar negeri AS untuk Yunani itu pula yang membuka tabir bagaimana geopolitik memengaruhi preferensi bantuan luar negeri suatu negara.

Diane B. Kunz (2007) memaparkan kompleksitas motif di balik pemberian bantuan luar negeri AS terhadap negara-negara Eropa Barat sewaktu Perang Dingin melalui skema European Recovery Program (ERP). Menurutnya, 
motif ekonomi dan politik saling berkelindan satu sama lain, sehingga memunculkan hubungan yang tidak terpisahkan antara stabilitas finansial dan stabilitas politik. Motif ekonomi di balik Marshall Plan/ERP berkaitan dengan keterbukaan pasar Eropa Barat bagi produk-produk AS dan keberlangsungan kapitalisme global secara umum. Saat itu, Presiden Truman yakin, keamanan nasional Amerika membutuhkan Eropa Barat yang sehat secara ekonomi. Krisis yang terjadi di Eropa pada tahun 1947 menjadi penanda awal kebenaran asumsi Truman tersebut. Di awal 1947 indikator ekonomi menunjukkan sedikit ke arah resesi. Para ekonom khawatir jika resesi bertepatan dengan penurunan daya beli Eropa akan terjadi efek domino yang berdampak pada perekonomian domestik. Untuk itu William L. Clayton mengatakan: "Let us admit right off that our objective has its background the needs and interests of the people of the United States. We need markets - big markets - in which to buy and sell." Para elit politik pada akhirnya menyetujui gagasan asistensi langsung AS terhadap Eropa Barat.

Sedangkan motif politik berkaitan dengan upaya untuk mencegah berkembangnya ideologi komunisme di Eropa Barat dan Selatan. Pada awal bulan Oktober, Uni Soviet bersama dengan partai-partai komunis, mengeluarkan manifesto untuk menghidupkan Komintern (Komunis Internasional). Komintern merupakan sebuah organisasi internasional yang bertujuan untuk merubah dunia ke dalam bentuk komunisme. Berita itu segera membunyikan alarm peringatan mengenai bahaya ancaman penyebaran komunisme. Sehingga muncul keyakinan, tanpa bantuan Amerika, negara-negara Eropa Barat akan jatuh ke tangan Uni Soviet. "Peringatan" tersebut semakin diperkuat dengan pemberitaan media mengenai penyebaran ideologi komunisme. Puncak dari dukungan masyarakat AS terhadap Marshall Plan adalah dikuasainya Czechoslovakia oleh pemerintah komunis pada bulan Februari. Para pendukung Marshall Plan tidak lagi ragu-ragu untuk mengingatkan Kongres dan masyarakat luas bahwa satu dekade yang lampau Barat telah menjual negara tersebut kepada Nazi. Dua bulan kemudian, pada tanggal 2 April 1947, Kongres meloloskan European Recovery Act, yang disahkan menjadi undang-undang sehari setelahnya.

Tulisan Diane Kunz di atas menunjukkan bagaimana faktor geopolitik sangat memengaruhi keputusan AS untuk memberikan bantuan luar negeri. Oleh sebab itu, sebelum membahas perang sipil di Yunani, perlu disinggung mengenai 
konsep geopolitik secara umum. Geopolitik secara sederhana dan umum didefinisikan sebagai praktek negara dalam penguasaan dan kompetisi atas teritori (Flint, 2006: 13). Sedangkan menurut Cohen (2010), geopolitik adalah:

(...) the analysis of the interaction between, on the one hand, geographical settings and perspectives and, on the other hand, political processes. (...) Both geographical settings and political processes are dynamic, and each influences and is influenced by the other. Geopolitics addresses the consequences of this interaction.

Dalam konteks Perang Dingin, tulisan George Kennan yang berjudul "The Sources of Soviet Conduct" dan "Doktrin Truman" menjadi rujukan penting bagaimana geopolitik bermain pada tataran realita. Di dalam sebuah artikel yang dimuat di majalah Foreign Affairs, Kennan menggunakan nama samaran "X" untuk menjelaskan bahwa Uni Soviet memiliki tendensi ekspansionis karena dipengaruhi oleh ideologi Marxis-Leninis. Di bawah pengaruh ideologi tersebut Rusia berniat untuk menjatuhkan kapitalisme di seluruh dunia dengan memperluas pengaruhnya baik secara langsung maupun tidak langsung. Oleh sebab itu Kennan menyarankan agar AS melakukan politik "pembendungan” agar pengaruh Uni Soviet tidak lebih jauh lagi menyebar. Tulisan panjang tersebut kemudian menarik perhatian Presiden Truman yang pada saat bersamaan mendapatkan kabar buruk dari perwailan AS di Yunani. Di dalam pidatonya yang berjudul "Doktrin Truman", Presiden Truman mencemaskan masa depan Yunani dan Turki yang rawan jatuh ke tangan rezim komunis dengan munculnya gerakan-gerakan pemberontakan oleh golongan komunis (Karvounarakis, 2006). Untuk itu Truman mengatakan:

I believe that it must be the policy of the United States to support free peoples who are resisting attempted subjugation by armed minorities or by outside pressure. I believe that we must assist free peoples to work out their own destinies in their own way. I believe that our help should be primarily through economic and financial aid which is essential to economic stability and orderly political processes...

Dinamika tersebut seakan menguatkan tesis "bapak geopolitik" Halford Mackinder mengenai teori "jantung dunia" (heartland). Di dalam artikelnya yang berjudul "The Geographical Pivot of History” (1904), Mackinder mengemukakan: "Barangsiapa berkuasa atas Eropa Timur akan menguasai 'jantung dunia'. Barangsiapa berkuasa atas 'jantung dunia' akan menguasai 'daratan dunia'. Barang 
siapa berkuasa atas 'daratan dunia' akan menguasai dunia". "Jantung dunia" menurut Mackinder merupakan keseluruhan daratan Eurasia, sedangkan "daratan dunia" merupakan Eropa, Asia, dan Afrika. Dalam konteks Perang Dingin, baik Uni Soviet dan Amerika Serikat "bertarung" untuk memperebutkan pengaruh atas Eropa Timur, meski dengan cara yang sedikit berbeda. Uni Soviet lebih condong menggunakan kekuatan militer dan ideologi, sedangkan Amerika Serikat menggunakan ideologi yang diperkuat dengan bantuan finansial.

\section{Perang Sipil Yunani 1946-1949}

Yunani dan Turki merupakan dua negara yang terlibat dalam Perang Dingin tanpa ada keterlibatan langsung dari pasukan bersenjata Uni Soviet. Di awal periode Perang Dingin rakyat Yunani tercabik-cabik oleh perang saudara. Akibat dari perang saudara, rakyat Yunani kehilangan sepuluh persen dari total jumlah penduduknya - lebih buruk dari jumlah korban karena Perang Dunia II yang menyentuh angka delapan persen dari jumlah penduduk (Nachmani, 1990).

Sedangkan Turki masih lebih beruntung karena pengaruh komunisme belum sempat berkembang. Meski begitu, secara geopolitik Turki merupakan sasaran yang strategis bagi Uni Soviet untuk memperluas pengaruhnya. Terbukti, Uni Soviet mendesak Turki untuk melepaskan kontrolnya atas Selat Bosporus kepada para penguasa Laut Hitam (Satterthwaite, 1972). Hal ini semakin memperkuat asumsi Truman bahwa Amerika Serikat harus mengambil tindakan "membendung" pengaruh Uni Soviet di dua negara tersebut. Guna mempertajam analisis, bagian ini hanya membahas perang sipil Yunani yang terjadi di pertengahan dekade 1940-an.

Perang sipil di Yunani disebabkan oleh pertarungan dua kekuatan besar untuk menentukan jiwa suatu negara: apakah menjadi komunis-Timur atau liberalBarat. Perang sipil Yunani berakar pada instabilitas politik pasca Perang Dunia II. Segera setelah PD II berakhir, terdapat dua kelompok pemberontak yang ingin menjatuhkan rezim Nazi di Yunani: kelompok komunis EAM-ELAS (Ethnikón Apeleftherotikón Métopon-Ethnikós Laïkós Apeleftherotikós Strátos; "National Liberation Front-National Popular Liberation Army”); dan kelompok pro-kerajaan EDES (Ellínikos Dímokratikos Ethnikós Strátos; "Greek Democratic National Army"). Setelah keduanya berhasil menjatuhkan pemerintahan Nazi, muncullah 
perseteruan baru di antara mereka sendiri. Kelompok komunis menolak untuk membubarkan pasukan gerilyawan, dan memutuskan untuk memberontak. Meski sempat dikalahkan oleh pasukan bersenjata Inggris, pemberontakan kembali terjadi pada tahun 1946. Satu tahun setelahnya pemerintah Inggris mengumumkan bahwa mereka tidak mampu lagi memberikan bantuan militer dan finansial untuk mendukung rakyat Yunani (Powers, 1969).

Pada bulan Mei 1946 pemberontakan berlanjut. Negara-negara Balkan seperti Yugoslavia, Bulgaria, dan Albania diyakini menjadi pendukung kelompok pemberontak komunis Yunani, karena berbatasan langsung dengan daerah yang dikuasai oleh EAM - Macedonia, Thrace, Epirus. Daerah tersebut menjadi pusat pertempuran sehingga menyebabkan ribuan warganya mengungsi ke kota-kota besar. Meski mengalami banyak kekalahan, pemberontak komunis tetap bertahan karena dua alasan: pemerintah Yunani yang lemah serta adanya konflik perbatasan dengan Yugoslavia dan Albania.

Kecurigaan AS bahwa pemberontak komunis mendapatkan dukungan dari Uni Soviet berdasarkan fenomena yang terjadi di Eropa Timur. Jatuhnya Czechoslovakia ke tangan rezim komunis di bawah dukungan Uni Soviet, dukungan rezim komunis Yugoslavia di bawah kepemimpinan Joseph Broz Tito, menjadi alarm keras semakin ekspansifnya negara yang menjadi sekutu AS sewaktu PD II tersebut. Pada bulan Oktober 1946, “Tentara Demokratis” Komunis dibentuk secara resmi, dengan dukungan dari Tito. Meski begitu, secara non-formal, pasukan tersebut telah dibentuk sejak tahun 1945, di kota kecil bernama Boulkes, sebelah barat daya Belgrade, Yugoslavia. Sejak saat itu Boulkes menjadi pusat pelatihan, pengaderan, serta indoktrinasi, para kader militer komunis dan gerilyawan ELAS. Tanpa dukungan penuh dari Tito, gerakan gerilyawan komunis tidak akan mampu berkembang dan menjalankan serangan yang terencana dan sistematis terhadap pospos strategis pemerintah Yunani (Iatrides dan Rizopoulos, 2000).

Kecurigaan AS di atas senada dengan pidato Winston Churchill yang menganggap Uni Soviet memasang "tirai besi" di antara Eropa Barat dan Timur (Jerman Timur, Polandia, Hungaria, Romania, Yugoslavia, dan Albania). Tirai tersebut dikhawatirkan akan terus meluas ke Eropa Barat, Asia, dan Timur Tengah jika tidak segera dihadang. Keyakinan bahwa Uni Soviet menganut ideologi marxis- 
leninis semakin memperkuat asumsi-asumsi geopolitis di era Perang Dingin (Nachmani, 1990).

Studi kasus di atas yang berlatar Perang Dingin merupakan contoh paling jelas mengenai bagaimana geopolitik sangat memengaruhi preferensi pemberian bantuan luar negeri. Namun apakah pandangan tersebut masih bisa dipertahankan di era globalisasi di mana perang ideologis telah selesai dan negara bukan lagi aktoraktor satu-satunya dalam hubungan internasional? Bagian selanjutnya akan membahas mengenai preferensi bantuan luar negeri di era pasca Perang Dingin. Secara lebih spesifik penulis akan membahas mengenai preferensi pemberian bantuan luar negeri AS dalam upaya memberantas terorisme global.

\section{Terorisme dan Geopolitik}

Pasca Perang Dingin preferensi bantuan luar negeri yang sangat dipengaruhi oleh faktor geopolitik masih sangat terasa. Meski karakteristik politik global telah berubah secara fundamental karena globalisasi, faktor geopolitik tetap menjadi pertimbangan utama negara-negara donor dalam memberikan bantuan luar negeri. Salah satu karakteristik yang merubah wajah politik global adalah munculnya aktor-aktor non-state yang bergerak pada ruang transnasional. Di antara beberapa isu yang muncul berkaitan dengan transnasionalisme adalah terorisme global (Lutz, 2008). Fenomena terorisme global berkembang pasca tragedi $9 / 11$ yang meruntuhkan menara kembar W'TC di Amerika Serikat. Sejak saat itu fokus kebijakan luar negeri AS, dan juga negara-negara Barat sekutunya, adalah perang melawan terorisme. Hal ini yang kemudian memengaruhi preferensi AS dan negara-negara donor lainnya dalam menyalurkan bantuan luar negerinya.

Fenomena terorisme global ini meski bersifat transnasional tidak bisa terlepas dari konteks geopolitik. Hal ini terlihat dari kebijakan AS dalam menyalurkan bantuan luar negerinya yang mengalami pergeseran locus setelah peristiwa 9/11. Berdasarkan data dari kantor manajemen dan pendanaan untuk program-program bantuan luar negeri, pada tahun 2004 pemerintah AS berfokus pada negara-negara yang berada pada garis terdepan dalam upaya memerangi terorisme.

Bantuan luar negeri itu berbentuk bantuan finansial, pelatihan, maupun dukungan-dukungan lainnya untuk pemerintah negara-negara sekutu AS. Negara- 
negara yang dimaksud "terdepan" dalam dokumen pemerintah AS tersebut adalah Afghanistan, Kolombia, Yordania, Pakistan, dan Turki. Perubahan locus tersebut dapat dilihat jelas dengan membandingkan negara sasaran penerima bantuan luar negeri AS pada tahun 1998-2001 dengan 2002-2005. Kesimpulan yang diperoleh adalah terjadi peningkat secara signifikan atas besaran bantuan kepada negara-negara di Timur Tengah seperti Irak, Afghanistan, Yordania, dan Palestina (Cassidy, 2010). Tabel di bawah menunjukkan pergeseran alokasi negara-negara penerima bantuan luar negeri AS. Negara-negara penerima bantuan terbanyak merupakan negara sekutu sekaligus yang dianggap sebagai "garis depan" dalam upaya pemberantasan terorisme, seperti Afghanistan, Israel, Pakistan, dan Mesir.

Jika pada bagian sebelumnya dijelaskan bahwa preferensi bantuan luar negeri AS berdasarkan upaya untuk membendung menyebarnya ideologi komunisme di Eropa, maka pasca peristiwa 11 September 2001 bantuan luar negeri digunakan sebagai alat dalam upaya memerangi terorisme. Dua negara yang mendapatkan porsi terbesar bantuan luar negeri sejak 2001 adalah Afghanistan dan Irak. Hal itu dimaksudkan sebagai upaya memerangi terorisme sekaligus rekonstruksi pasca serangan AS ke kedua negara tersebut. Terdapat enam program di dalam kerangka bantuan luar negeri sektor perdamaian dan keamanan, di antaranya adalah: counterterrorism; memerangi senjata pemusnah massal; operasi-operasi untuk menciptakan stabilitas dan keamanan; counternarcotics; kejahatan transnasional; serta mitigasi konflik dan rekonsiliasi (Tarnoff dan Lawson, 2011).

Pada alokasi bantuan luar negeri tahun 2010, negara-negara di Timur Tengah dan Asia Selatan seperti Israel, Mesir, Afghanistan, Irak, Pakistan, dan Yordania, menjadi penerima terbanyak. Khusus untuk Afghanistan dan Irak, pemerintah AS menambahkan nilai bantuan senilai 10,2 milyar dollar pada tahun 2010 untuk pelatihan dan bantuan persenjataan dari Kementerian Pertahanan AS. Selama rentang waktu 2002-2010, Irak dan Afghanistan telah menerima bantuan untuk rekonstruksi sebesar 104 milyar dollar AS. Bahkan dalam kurun waktu 20032004 sebesar 21 milyar dollar AS disalurkan kepada dua negara tersebut. Hal ini menunjukkan besarnya pengaruh geopolitik pada preferensi bantuan luar negeri AS (Tarnoff dan Lawson, 2011). 
Table 3.Top Recipients of U.S. Foreign Assistance, FY2000 \& FY2010

\begin{tabular}{|c|c|c|c|}
\hline \multicolumn{4}{|c|}{ (in millions of current US\$) } \\
\hline \multicolumn{2}{|c|}{ FY2000 } & \multicolumn{2}{|l|}{ FY2010 } \\
\hline Israel & 4,069 & Afghanistan & 4,102 \\
\hline Egypt & 2,053 & Israel & 2,220 \\
\hline Colombia & 899 & Pakistan & 1,807 \\
\hline West Bank/Gaza & 485 & Egypt & 1,296 \\
\hline Jordan & 429 & Haiti & 1,271 \\
\hline Russia & 195 & Iraq & 1,117 \\
\hline Bolivia & 194 & Jordan & 693 \\
\hline Ukraine & 183 & Kenya & 688 \\
\hline Kosovo & 165 & Nigeria & 614 \\
\hline Peru & 120 & South Africa & 578 \\
\hline Georgia & 112 & Ethiopia & 533 \\
\hline Armenia & 104 & Colombia & 507 \\
\hline Bosnia & 101 & West Bank/Gaza & 496 \\
\hline Indonesia & 94 & Tanzania & 464 \\
\hline Nigeria & 68 & Uganda & 457 \\
\hline
\end{tabular}

Dari data-data yang disampaikan di atas, Afghanistan dan Pakistan merupakan dua negara utama penerima bantuan luar negeri. Hal ini bukannya tanpa alasan, mengingat dua negara tersebut dianggap sebagai "rumah" dari kelompok ekstremis Taliban yang memiliki hubungan erat dengan Al-Qaeda - organisasi teroris pimpinan Osama bin Laden. Taliban menjadi pembicaraan utama hubungan internasional setelah gedung kembar WTC, di Amerika Serikat dihantam oleh teroris pada tanggal 11 September 2001. Taliban dituduh menyembunyikan dan menolak menyerahkan Osama bin Laden, tertuduh utama sebagai dalang peristiwa 9/11. Segera pasca peristiwa tersebut, pasukan Amerika dan sekutunya melakukan serangan ke Afganistan, dan membersihkan pemerintahan dari Taliban (Saikal, 2004).

Selain berhubungan erat dengan Afghanistan, gerilyawan Taliban juga kerap dikaitkan dengan Pakistan. Taliban menerapkan hukum syariah di kedua negara, Pakistan dan Afghanistan. Pakistan menolak anggapan sebagai salah satu "arsitek" Taliban. Akan tetapi, banyak dari warga negara Afganistan, yang tergabung dalam gerakan militan, merupakan lulusan dari madrasah Pakistan. Pakistan juga merupakan salah satu dari tiga negara, Arab Saudi dan Uni Emirat Arab, yang mengakui rezim Taliban pada pertengahan tahun 1990-an sampai 2001. 
Kecurigaan itu seakan terbukti ketika pasca kejatuhannya di Afghanistan, Taliban kembali muncul dengan kekuatan yang jauh lebih besar di Pakistan. Banyak peneliti melihat adanya koordinasi ganda di antara faksi dan militan Taliban. Faksi Taliban Pakistan Tehrik Taliban Pakistani (TTP) yang dipimpin oleh Hakimullah Mehsud, disalahkan atas puluhan kasus bom bunuh diri dan serangan-serangan lainnya. Sedangkan Taliban Pakistan sendiri tetap yakin bahwa mereka dipimpin oleh Mullah Omar, seorang pemuka agama yang kehilangan mata kanannya sewaktu Uni Soviet menguasai Afganistan pada tahun 1980-an (Saikal, 2004).

Faktor-faktor tersebut yang memengaruhi preferensi geopolitik bantuan luar negeri AS pasca peristiwa 9/11. Sehingga, meski sempat menghentikan aliran bantuan luar negerinya untuk Pakistan karena uji coba nuklir, AS kembali menggelontorkan bantuan dengan nilai yang sangat besar. Antara tahun 2002 dan 2008, Pakistan menerima bantuan sebesar 12 milyar dollar AS. Bantuan tersebut merupakan dana yang diperuntukkan sebagai upaya pemberantasan terorisme. Disebutkan bahwa sebanyak 81 persen bantuan luar negeri yang disalurkan oleh AS bermuara di Pakistan. Bahkan pada tahun 2007, AS disebut-sebut memberikan bantuan setara seperempat total anggaran militer Pakistan (Ibrahim, 2009).

Figure 1.1 Historical U.S. Engagement with Pakistan, FY 1977-2007

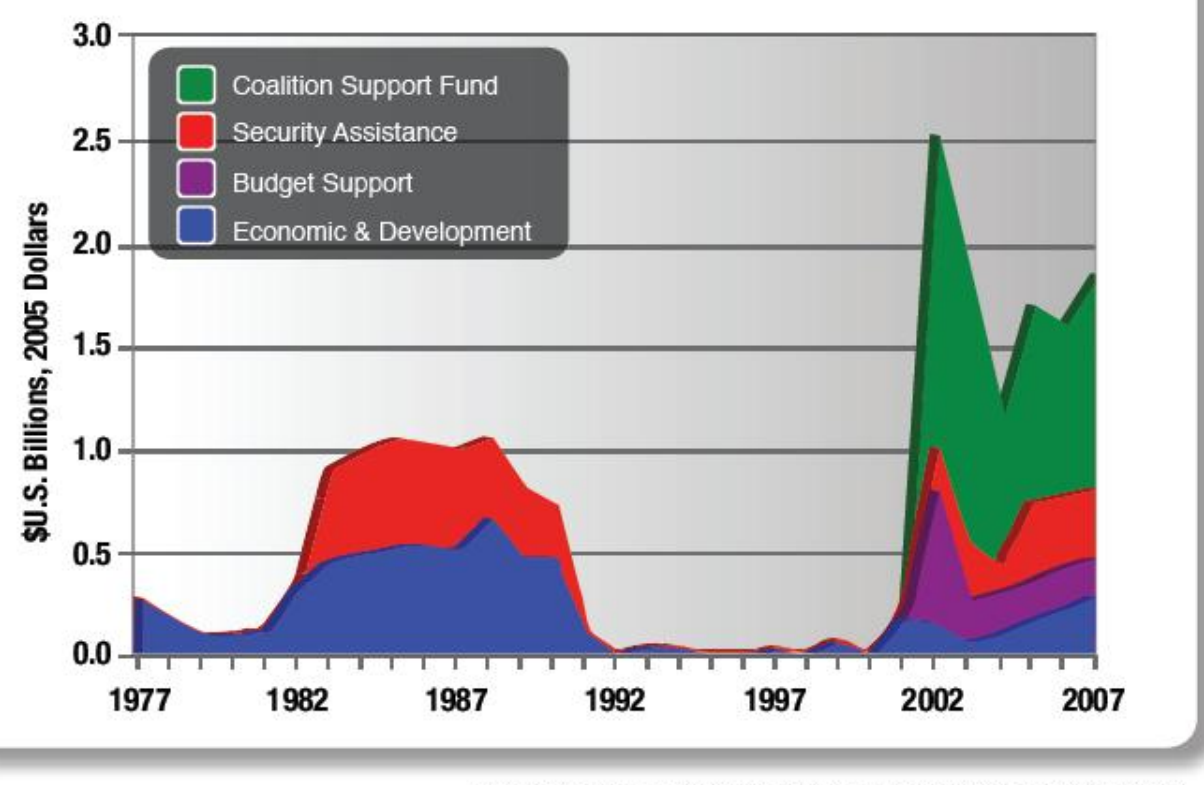

Note: Data from USAID Greenbook and Table A.1. Data do not include covert assistance. 
Grafik di atas menunjukkan bagaimana naik-turunnya bantuan luar negeri Amerka Serikat terhadap Pakistan. Seperti yang terlihat dari grafik tersebut, bantuan luar negeri Amerika Serikat terhadap Pakistan antara tahun 1992- 2000-an menurun drastis jika dibandingkan dengan dekade 1980-an. Hal itu disebabkan oleh sanksi yang diterapkan Amerika Serikat karena percobaan nuklir Pakistan. Sedangkan semenjak tahun 2001 bantuan luar negeri Amerika Serikat terhadap Pakistan kembali melonjak drastis akibat peristiwa 9/11 dan diterapkannya kebijakan "war on terrorism".

Analisis di atas menunjukkan bahwa meski globalisasi telah memunculkan aktor-aktor baru dalam politik internasional tetap tidak mengurangi arti penting geopolitik - khususnya terhadap preferensi pemberian bantuan luar negeri. Geopolitik masih menjadi alasan utama bagi negara sebelum memutuskan memberikan bantuan luar negerinya. Asumsi ini memperkuat asumsi lainnya yang beranggapan bahwa pembangunan ekonomi (economic development) merupakan alasan utama di balik pemberian bantuan luar negeri.

\section{Kesimpulan}

Berdasarkan pemaparan di atas, terbukti bahwa faktor geopolitik sangatlah memengaruhi preferensi bantuan luar negeri AS, baik dulu maupun sekarang. Meski fenomena tersebut terjadi di era Perang Dingin, kesimpulan ini tetap relevan dengan perkembangan politik bantuan luar negeri dewasa ini. Bantuan luar negeri AS terhadap Afghanistan dan Irak sebagai upaya counter-terrorism pada tahun 2009 merupakan contoh nyata bagaimana faktor-faktor geopolitik masih sangat memengaruhi preferensi pemberian bantuan luar negeri. Perubahan fundamental politik internasional dewasa ini memang memungkinkan aktor non-negara ikut bermain di dalamnya, namun hal tersebut tidak merubah nature geopolitiknya. Persinggungan antara politik dan geografi akan selalu memengaruhi preferensi pemberian bantuan luar negeri suatu negara.

\section{Daftar Pustaka}

Azam, Jean-Paul dan Thelen, Véronique. 2015 “The Geo-Politics of Foreign Aid and Transnational Terrorism”, 5 Oktober 2015, 
http://idei.fr/sites/default/files/medias/doc/by/azam/geopoliticsofAid2.pdf

Cahnman, Werner J. 1943. "Concepts of Geopolitics", American Sociological Review, Vol. 8, No. 1, hal. 57.

Calderisi, Robert. 2006. "The Trouble with Foreign Aid", dalam The Trouble with Africa: Why Foreign Aid Isn't Working?. New York: Palgrave Macmillan.

Cassidy, Traviss. 2010. "How Foreign Aid Affects Terrorism: Studying the Channel of Social Spending". Issues in Political Economy, Vol 19, hal. 69-95.

Cohen. 2010. "Geopolitics of the World System," 15 Juni 2010, http://www.exploringgeopolitics.org/PublicationEfferink_van_Leonhar dt_The_Definition_of_Geopolitics_Classicial_French_Critical.html.

Collier, Paul dan David Dollar. 2004. "Development Effectiveness: What We Have Learnt?". The Economic Journal, No. 114, hal. 244-271.

Easterly, William. 2003. "Can Foreign Aid Buy Growth?”. TheJournal of Economics Perspectives, Vol. 17, No. 3, hal. 23-48.

Grant, Richard dan J. Nijman. 1998. "Foreign Aid to Africa: the Rise and Fall of Structural Development Aid”, dalam Grant, Richard dan J. Nijman (ed.). 1998. The Global Crisis in Foreign Aid. Syracuse: Syracuse University Press.

Heertz, Noreena. 2004. "Can't Pay, Won't Pay”, dalam The Debt Threat: How Debt is Destroying the Developing World. New York: Harper Bussines.

Iatrides, John O., dan Rizopoulos, Nicholas X. 2000. “The International Dimension of the Greek Civil War". World Policy Journal, Vol. 17, No. 1 (Spring), hal. 87-103

Ibrahim, Azeem. Belfer Center Discussion Paper \#2009-06, International Security Program, Harvard Kennedy School, July 2009.

Karvounarakis, Theodosis. 2015. 'In Defense of 'Free Peoples': The Truman Doctrine and its Impact on Greece During the Civil War Years, 19471949,5 Oktober 2015, http://www.eliamep.gr/old/eliamep/files/op0106.PDF.

Kunz, Diane B. 2007. "The Marshall Plan Reconsidered: A Complex of Motives", Foreign Affairs, Vol. 76, No. 3, hal. 162-170. Lutz, James M. dan Brenda J. Lutz. 2008. Global Terrorism. Oxon: Routledge. 
Mackinder, Halford J. 1904. "The Geographical Pivot of History". The Geographical Journal, Vol. 23. No. 4 (April), hal. 421-437.

Nachmani, Amikamm. 1990. "Civil War and Foreign Intervention in Greece: 194649, Journal of Contemporary History, Vol. 25, No. 4 (Oktober), hal. 489-522.

Parvitt, Trevor W. 1986. “Africa and the Debt Trap: Which Way Out”. The Journal of Modern Africa Studies, Vol. 24, No. 3, hal 519-527.

Powers, Richard J. 1969. “Containment: From Greece to Vietnam, and Back?”. The Western Political Quarterly, Vol. 22, No. 4 (Desember), hal. 846-861

Saikal, Amin, 2004. Modern Afghanistan: A History of Struggle and Survival. I.B. Tauris \& Co Ltd.

Satterthwaite, Joseph C. 1972. "The Truman Doctrine: Turkey". The Annals of the American Academy of Political and Social Science, Vol. 401, America and the Middle East (Mei), hal. 74-84.

Tarnoff, Curt dan Lawson, Marian Leonardo. 2011. "Foreign Aid: An Introduction to U.S. Programs and Policy". Congressional Research Service, February 10, 2011.

Woods, Ngaire, 2006. "The Mission in Mexico", dalam The Globalizers: the IMF, the World Bank and Their Borrowers. Ithaca: Cornell University Press. 